\title{
FIRST RECORD OF Ctenogobius smaragdus (VALENCIENNES, 1837) (GOBIIFORMES, GOBIIDAE) FOR THE MARANHÃO STATE, BRAZILIAN AMAZON COAST
}

\section{Running title FIRST RECORD OF CTENOGOBIUS SMARAGDUS}

Pâmella Silva de Brito ${ }^{1,2}$, Erick Cristofore Guimarães ${ }^{1,2}$, Clarence de Castro Ramos Junior ${ }^{3}$, Felipe Polivanov Ottoni ${ }^{1,2,4,5}$, Jorge Luiz Silva Nunes ${ }^{1,4,6}$

${ }^{1}$ Universidade Federal do Maranhão, Programa de Pós-Graduação em Biodiversidade e Biotecnologia da Amazônia Legal. Av. dos Portugueses 1966, Cidade Universitária do Bacanga, CEP 65080-805, São Luís, MA, Brasil.

${ }^{2}$ Universidade Federal do Maranhão, Laboratório de Sistemática e Ecologia de Organismos Aquáticos, Centro de Ciências Agrárias e Ambientais, Campus Universitário, CCAA, BR-222, KM 04, S/N, Boa Vista, CEP 65500-000, Chapadinha, MA, Brasil.

${ }^{3}$ Universidade Federal do Maranhão, Departamento de Biologia, Laboratório de Genética e Biologia Molecular, Av. dos Portugueses 1966, Cidade Universitária do Bacanga, CEP 65080-805, São Luís, MA, Brasil.

${ }^{4}$ Universidade Federal do Maranhão, Programa de Pós-Graduação em Biodiversidade e Conservação. Av. dos Portugueses 1966, Cidade Universitária do Bacanga, CEP 65080-805, São Luís, MA, Brasil.

${ }^{5}$ Universidade Federal do Maranhão, Programa de Pós-graduação em Ciências Ambientais, Centro de Ciências Agrárias e Ambientais, Campus Universitário, CCAA, BR-222, KM 04, S/N, Boa Vista, CEP 65500-000, Chapadinha, MA, Brasil.

${ }^{6}$ Universidade Federal do Maranhão, Laboratório de Organismos Aquáticos, Departamento de Oceanografia e Limnologia. Av. dos Portugueses 1966, Cidade Universitária do Bacanga, CEP 65080-805, São Luís, MA, Brasil. Autor correspondente: Pâmella Silva de Brito (pamellabrito@hotmail.com)

ABSTRACT
This study presents the first records of Ctenogobius smaragdus for the Maranhão State, found at the
Raposa Channel Estuary, Brazilian Amazon Coast. The lack of previous records could be justified
by the use of inappropriate sampling methods and the focus of previous researches in Maranhão.
Key words: Emerald goby, Equatorial Coast, Mangrove, Macrotidal environment, Estuary system.
RESUMO
O presetnte estudo registra pela primeira vez Ctenogobius smaragdus para o Estado do Maranhão,
o exemplar foi encontrado no canal da Raposa, Costa Amazônica Brasileira. A falta de registro
no pretérito pode ser justificada pelo uso de metódos inapropriados e diferentes foco dos estudos
localizados no Maranhão.
Palavras-chave: maré, litoral equatorial, manguezais, macromarés, sistemaa estuarino.

\section{INTRODUCTION}

Gobiidae of the largest fish families comprising more than 1.900 species (Fricke et al. 2019). Most species occur in the tropical Indo-West Pacific, but the family extends well into temperate waters of both the Northern and Southern hemispheres (Nelson et al., 2016).

The genus Ctenogobius Gill, 1858 currently comprises 12 species recognized as valid in the Atlantic Ocean: Ctenogobius boleosoma (Jordan \& Gilbert, 1882); C. claytonii (Meek, 1902); C. fasciatus Gill, 1858; C. lepturus (Pfaff, 1933); C. phenacus (Pezold \& Lasala, 1987); C. pseudofasciatus (Gilbert \& Randall, 1971); C. saepepallens (Gilbert \& Randall, 1968); C. shufeldti (Jordan \& Eigenmann, 1887); C. smaragdus (Valenciennes, 1837); $C$. stigmaticus (Poey, 1860); C. stigmaturus (Goode
\& Bean, 1882) and C. thoropsis (Pezold \& Gilbert, 1987) (Fricke et al., 2019). The species richness is high in Brazil, with six species occurring in the Brazilian coastal region (Guimarães et al., 2017a; Froese \& Pauly, 2019).

The emerald goby Ctenogobius smaragdus is distributed from South Carolina (USA) to Barra do Saí, Santa Catarina state (Brazil), being absent in the Antilles, except Cuba; occurring in the following Brazilian states: Pará, Ceará, Rio Grande do Norte; Paraíba, Pernambuco, Bahia, Espírito Santo, São Paulo, Paraná and Santa Catarina (Rosa, 1980; Alves \& Soares-Filho, 1996; Joyeux et al., 2004; Mourão \& Nordi, 2006; Vendel \& Chaves, 2006; SarmentoSoares et al., 2007; Paiva et al., 2008; Gomes-Filho \& Rosa, 2009; Paiva \& Araujo, 2010; Reis-Filho et 
al., 2010; Menezes, 2011; Passos et al., 2012; LimaFilho, 2015; Oliveira et al., 2016; Froese \& Pauly, 2019). The present study presents the first record of $C$. smaragdus for the Maranhão State, Brazilian Amazon Coast.

\section{METHODS}

Five specimens of C. smaragdus (Figure 1) were collected at the Raposa Channel Estuary near Paciencia River Estuary, north of the Ilha do Maranhão, Maranhão State, Amazon Coast (Figures 2 and 3). The sampling was conducted during daytime, using a manual trail-net $(20 \mathrm{~m}$ a long $\mathrm{x} 5 \mathrm{~m}$ high; mesh size, $5 \mathrm{~mm}$ ). This net was trawled two times, by two collectors, through the salt marsh bed composed of Spartina alterniflora L., during low tide (Figure 3). The collected specimens were fixed in $10 \%$ formalin just after capture, and transferred to $70 \%$ alcohol for preservation, after 10 days. The materials were analyzed and deposited in the Coleção Ictiológica do Centro de Ciências Agrárias e Ambientais of the Universidade Federal do Maranhão (CICCAA). Sampling was authorized by IBAMA/ SISBIO, license $\mathrm{N}^{\circ}$ 30346-1.

\section{RESULTS}

\section{Ctenogobius smaragdus (Valenciennes, 1837)}

Gobius smaragdus Valenciennes, 1837:120. Type locality: Cuba. Holotype: MNHN A-1257.

New records. Ctenogobius smaragdus, CICCAA 00203, 5 specimens, 46.2-158,1 mm SL, Raposa Channel Estuary, Maranhão, Brazil, $02^{\circ} 25^{\prime} 22^{\prime \prime} \mathrm{S} 44^{\circ} 05^{\prime} 21^{\prime \prime} \mathrm{W}$, Brito and A. Ramos, 06 June 2013.

Diagnosis. Ctenogobius genus is identified by the presence of a short lateral cephalic canal with only two pores, no gill rakers or lobes on upper limb of first gill arch, four or five gill rakers on lower limb of first gill arch, and gill rakers short and triangle shaped (Smith, 1997; Murdy \& Hoese, 2002; Ross \& Rhode, 2004). The specimens CICCAA 00203, 5, 46.2-158,1 mm SL (Figure 1) have scaled predorsal area, head and body with many black-encircled, cream-colored spots, 42 scales on lateral row and large canine teeth in both jaws; which are diagnostic features of $C$. smaragdus (Smith, 1997; Murdy \& Hoese, 2002; Ross \& Rhode, 2004; Froese \& Pauly, 2019).

\section{DISCUSSION}

This present paper brings a record of the $C$. smaragdus for Maranhão State and reduces the gaps in the geographical distribution for Emerald goby in the Amazon Coast. This area is very important because it divides the Caribbean and Brazilian biogeographic provinces (Rocha, 2002; Pinheiro et al., 2018).

In addition, most of the inventories and studies including marine and estuarine ichthyofauna of the Maranhão State have been used sampling methodologies such as gill nets, corking nets, and longline, which are not efficient to collect small sized specimens, and usually focusing on large-sized species, with fisheries importance (e.g. Martins-Juras et al., 1987; Rocha \& Rosa, 2001; Ribeiro \& Castro, 2003; Santos et al., 2003; Araújo-Júnior et al., 2005; Pinheiro-Júnior et al., 2005; Carvalho-Neta \& Castro, 2008; Nunes et al., 2011).

The present record of the $C$. smaragdus was possibly due to the current change of the focus on ichthyology researches in this region. Besides the previous researches had aim to describe: traditional catches methodologies (e.g. Piorski et al., 2009), traditional fisheries (e.g. Nunes et al., 2005; Almeida et al., 2010; Almeida et al., 2011), commercial fish species (e.g. Almeida \& Pinheiro, 2013; CarvalhoNeta et al., 2016), populational dynamic (e.g. Lima et al., 2009; Azevedo et al., 2010; Azevedo et al., 2017), environmental assessment (e.g. Soares et al., 2011; Sousa et al., 2011; Castro et al., 2018). Recently, there is an increase of researches focusing on tide pools and tidal regions (e.g. Lasso-Alcalá et al., 2011; Coelho et al., 2013; Mendes et al., 2017; Guimarães et al., 2017b) and the explorations in different environmental used by small sized marine/ estuarine fishes, and/or juveniles (e.g. Coelho, 2013; Brito, 2014; Guimarães et al., 2017a).

Therefore, we conclude that in order to obtain new records of small fish species or cryptic behaviors present in different environments in Maranhão State (e.g. Blenniidae, Eleotridae, Gobiidae, Labrisomidae), it will be necessary to use appropriate capture methodologies.

\section{Acknowledgements}

Thanks are due to Cláudio Sampaio for providing the photograph of the life specimen, 
and Axel Katz for this image edition; Albertina Ramos, Lucas Percilio, Dorivaldo Pereira and Francisco de Assis for assistance in field work; and Clarisse Figueiredo for her help with translating and revising the manuscript. This study was supported by FAPEMA (Fundação de Amparo à Pesquisa e Desenvolvimento Científico do Maranhão/ process number 00318/11). The author JLSN thanks to FAPEMA by Productivity Scholarship.

\section{REFERENCES}

ALMEIDA, Z. S., ISAAC-NAHUM, V. J., SANTOS, N. B. \& PAZ, A. C. 2010. Diagnóstico dos sistemas de produção pesqueiro artesanais do litoral do Maranhão. São Luís: Editora UEMA. 126p.

ALMEIDA, Z. S., ISAAC, V. J., PAZ, A. C., MORAIS, G. C. \& PORTO, H. L. R. 2011. Avaliação do Potencial de Produção Pesqueira do Sistema da Pescada-Amarela (Cynoscion acoupa) capturada pela frota comercial do Araçagi, Raposa, Maranhão. Bol. Lab. Hidrobiol., 24: 35-42.

ALMEIDA, Z. S. \& PINHEIRO, A. L. R. 2013. Recursos pesqueiro da costa maranhense: bioecologia, pesca e biomonitoramento. São Luís: Associação Brasileira das Editoras Universitárias. 107p.

ALVES, M. I. M. \& SOARES-FILHO, A. A. 1996. Peixes do Estuário do Rio Jaguaribe (Ceará -Brasil): Aspectos Fisioecológico. Ciência Agronômica, 1/2 (27): 9-18.

ARAÚJO-JÚNIOR, E. S., PINHEIRO-JÚNIOR, J. R. \& CASTRO, A. C. L. 2005. Ictiofauna acompanhante da pesca do camarão branco, Penaeus (Litopenaeus) schmitti Burkenroad (1936) no estuário do Rio Salgado, Alcântara-MA. Bol. Lab. Hidrobiol., 18(1): 33-41.

AZEVEDO, J. W. J., CASTRO, A. C. L., PORTO, H. L. R. \& LIMA, P. R. S. 2010. Size and age at first maturity of the crucifix sea catfish, Sciades proops (Valenciennes, 1840) (Siluriformes: Ariidae), caught off western Maranhão State, Brazil. Arq. Cienc. Mar, 43: 2-102.

AZEVEDO, J. W. J., CASTRO, A. C. L. \& Silva, M. H. L. 2017. Length-weight relation, condition factor and gonadosomatic index of the whitemouth croaker, Micropogonias furnieri (Desmarest, 1823) (Actinopterygii: Sciaenidae), caught in Lençóis Bay, state of Maranhão, eastern Amazon, Brazil. Braz. J. Oceanogr., 65: 1-8.

BRITO, P. S. de. 2014. Estrutura de comunidades de peixes associados a bancos de fanerógamas marinhas da Ilha do Maranhão, Maranhão, Brasil. Master Science Thesis (Biodiversity and Conservation), Universidade Federal do Maranhão. 85p.

CARVALHO-NETA, R. N. F. \& A.C.L. CASTRO. 2008. Diversity of the estuarine fish assemblages on Crabs Island, Maranhão State. Arq. Cienc. Mar, 41(1): $48-57$.

CARVALHO NETA, R. N. F., ALMEIDA, Z. S. \& SANTOS, D. 2016. Metodologias e Pesquisas em Recursos Aquáticos e Pesca: Um Guia Prático. São Luís: UEMA, 274p.

CASTRO, A. C. L., ESCHRIQUE, S. A., SILVEIRA, P. C. A., AZEVEDO, J. W. J., FERREIRA, H.R.S., SOARES, L. S., MONTELES, J. S., ARAUJO FILHO, M., NUNES, J. L. S. \& SILVA, M. H. L. 2018. Physicochemical properties and distribution of nutrients on the inner continental shelf adjacent to the Gulf of Maranhão (Brazil) in the equatorial Atlantic. Appl. Ecol. Env. Res., 16: 4829-4847.

COELHO, G. K. F. 2013. Estrutura de comunidade de peixes de poças de marés em praias arenosas do Ilha do Maranhão. Master Science Thesis (Biodiversity and Conservation), Universidade Federal do Maranhão, 110p.

COELHO, G. K. F., NOGUEIRA, L. A., BRITO, P. S., PIORSKI, N. M. \& NUNES, J. L. S. 2013. Use of tide pools as spawning site by Amphichthys cryptocentrus (Batrachoidiformes: Batrachoididae), state of Maranhão, Brazil. Cybium, 37: 227-228.

FRICKE R. \& ESCHMEYER W.N. 2019. Guide to fish collections. http://researcharchive.

$<$ http://researcharchive.calacademy.org $>$ last access in: 10/02/2019.

FRICKE, R., ESCHMEYER, W. N. \& VAN DER LAAN R. 2019. Genera, Species, References. Catalog of Fishes. Available in: <http://researcharchive. calacademy.org > last access in: 10/02/2019.

FROESE, R. \& PAULY, D. FishBase. 2019. World Wide Web electronic publication, 2007. Available in: $<$ http://www.fishbase.org > last access in: 10/02/2019.

GOMES-FILHO, G. \& ROSA, R. S. 2009. Inventário da ictiofauna da bacia do rio Gramame - PB, Brasil. pp 167-175 In: BARBOSA, J. E. L, WATANABE, T \& PAZ, RJ. (orgs.). A bacia do Rio Gramame: biodiversidade, uso e conservação. Campina Grande: EDUEPB, 229p.

GUIMARÃES, E. C., BRITO, P. S., OTTONI, F. P., 
KATZ, A. M., NUNES, J. L. S. \& SAMPAIO, C. L. S. 2017a. Pisces, Gobiiformes, Gobiidae, Ctenogobius boleosoma (Jordan \& Gilbert, 1882): first record for Maranhão State, northeastern Brazil. Check List, 13(3): 2120.

GUIMARÃES, E. C., BRITO, P. S. \& OTTONI, F. P. 2017d. First record of Butis koilomatodon (Bleeker, 1849) (Gobiiformes: Eleotridae) for the Maranhão state, northeastern Brazil: a case of bioinvasion. Cybium, 41(3): 299-300.

JOYEUX, J. C., PEREIRA, B. B. \& ALMEIDA, H. G. 2004. The flood-tide ichthyoplanktonic community at the entrance into a Brazilian tropical estuary. J. Plankton Res., 26(11): 1277-1287.

LASSO-ALCALÁ, O., NUNES, J. L. S., LASSO, C., POSADA, J., ROBERTSON, R., PIORSKI, N. M., TASSEL, J., GIARRIZO, T. \& GONDOLO, G. 2011. Invasion of the Indo-Pacific blenny (Perciformes, Blennidae) on the Atlantic Coast of Central and South America. Neotrop. Ichthyol., 9: 571-578.

LIMA, P. R. S., LESSA, R., CASTRO, A. C. L. \& AZEVEDO, J. W. J. 2009. Tamanho e idade de primeira maturação do serra, Scomberomorus brasiliensis Collette Russo \& Zavalla-Camin,1978) (Osteichthyes; Scombridae) no litoral ocidental do Maranhão - Brasil. Bol. Lab. Hidrobiol., 22: 47-52.

LIMA-FILHO, P. A. 2015. Diversidade cromossômica e padrões ecomorfológicos em Gobiidae (Perciformes) no litoral e ilhas oceânicas do Brasil. Master Science Thesis (Ecology), Universidade Federal do Rio Grande do Norte. 155p.

MARTINS-JURAS, I. A. G. M., JURAS, A. A. \& MENEZES, N. A. 1987. Relação preliminar dos peixes da ilha de São Luís, Maranhão, Brasil. Rev. Bras. Zool., 4(2):105-113.

MENDES, M. B. P., MARTINS, A. P. B., COELHO, G. K. F., PIORSKI, N. M. \& NUNES, J. L. S. 2017. Non-native mud sleeper Butis koilomatodon (Bleecker, 1849) (Perciformes: Eleotridae) in Eastern Amazon Coastal region: an additional occurrence for the Brazilian coast and urgency for ecological assessment. Bioinvasion Rec., 6: 111 - 117.

MENEZES, N. A. 2011. Checklist dos peixes marinhos do Estado de São Paulo, Brasil. Biota Neotrop., 1(1): 33-46.

MOURÃO, J. S. \& NORDI, N. 2006. Pescadores, peixes, espaço e tempo: Uma abordagem etnoecológica. Interciencia, 31(5): 358-363.
MURDY, E. O. \& HOESE, D. F. 2002. Gobiidae; pp. 601-1374, In: CARPENTER, K. E. 2002. The living marine resources of the Western Central Atlantic. Vol. 2. Bony fishes, part 1 (Acipenseridae to Grammatidae). FAO Species Identification Guide for Fishery Purposes and American Society of Ichthyologists and Herpetologists Special Publication. Rome: FAO.

NELSON, J. S., GRANDE, T. C. \& WILSON, M. V. H. 2016. Fishes of the world. New Jersey: John Wiley \& Sons. 651p.

NUNES, J. L. S., ALMEIDA, Z. S. \& PIORSKI, N. M. 2005. Raias capturadas pela pesca artesanal em águas rasas do Maranhão - Brasil. Arq. Cienc. Mar, 38: 49-54.

NUNES, J. L. S., SILVA, N. K. A. \& PIORSKI, N. M. 2011. Lista de peixes marinhos e estuarinos do Maranhão. pp. 175-196. In: NUNES, J. L. S. \& PIORSKI, N. M. (Org.). Peixes Marinhos e Estuarinos do Maranhão. São Luís: Café \& Lápis.

OLIVEIRA, R. R. DE S., MACIEIRA, R. M. \& GIARRIZZO, T. 2016. Ontogenetic shifts in fishes between vegetated and unvegetated tidepools: assessing the effect of physical structure on fish habitat selection. J. Fish Biol., 89(1): 959-976.

PAIVA, A. C. G., CHAVES, P. T. C. \& ARAÚJO, M. E. 2008. Estrutura e organização trófica da ictiofauna de águas rasas em um estuário tropical. Rev. Bras. Zool., 25(4): 647-661.

PAIVA, A. C. G. \& ARAÚJO, M. E. 2010. Environmental characterization and spatial distribution of fish fauna in estuaries in the state of Pernambuco, Brazil. Trop. Oceanogr., 38(1): $1-46$.

PASSOS, A. C., CONTENTE, R. F., ARAÚJO, C. C. V., DAROS, F. A. L. M., SPACH, H. L., ABILHÔA, V. \& FÁVARO, L. F. 2012. Fishes of Paranaguá Estuarine Complex, South West Atlantic. Biota Neotrop., 12(3): 226-238.

PINHEIRO, H. T., ROCHA, L. A., MACIEIRA, R. M., CARVALHO-FILHO, A., ANDERSON, A. B., BENDER, M. G., DI DARIO, F., FERREIRA, C. E. L., FIGUEIREDO-FILHO, J., FRANCINIFILHO, R., GASPARINI, J. L., JOYEUX, J. C., LUIZ, O. J., MINCARONE, M. M., MOURA, R. L., NUNES, J. A. C. C., QUIMBAYO, J. P., ROSA, R. S., SAMPAIO, C. L. S., SAZIMA, I., SIMON, T., VILA-NOVA, D. A. \& FLOETER, S. R. 2018. South-western Atlantic reef fishes: 
Zoogeographical patterns and ecological drivers reveal a secondary biodiversity centre in the Atlantic Ocean. Diversity and Distributions, 24: 951-965. 10.1111/ddi.12729

PINHEIRO-JÚNIOR, J. R., CASTRO, A. C. L. \& GOMES, L. N. 2005. Estrutura da comunidade de peixes do estuário do rio Anil, Ilha de São Luís, Maranhão. Arq. Cienc. Mar., 38: 29-37.

PIORSKI, N. M., SERPA, S. S. \& NUNES, J. L. S. 2009. Análise comparativa da pesca de curral da Ilha do Maranhão, Maranhão - Brasil. Arq. Cienc. Mar, 42: 65-71,

REIS-FILHO, J. A., NUNES, J. A. C. C. \& FERREIRA, A. 2010. Estuarine ichthyofauna of the Paraguaçu River, Todos os Santos Bay, Bahia, Brazil. Biota Neotrop., 10(4): 301-312.

RIBEIRO, D. \& CASTRO,A.C. L. 2003. Contribuição ao Estudo da Dinâmica Populacional do Tralhoto Anableps anapleps (Teleostei, Cyprinodontidae) no Município de Bacuri, Estado do Maranhão. Bol. Lab. Hidrobiol., 16: 21-27.

ROCHA, L. A. \& ROSA, I. S. 2001. Baseline assessment of reef fish assemblages of Parcel Manuel Luiz Marine State Park, Maranhão, north-east Brazil. J. Fish Biol., 58: 985-998.

ROCHA, L. A. 2003. Patterns of distribution and processes of speciation in Brazilian reef fishes. Journal of Biogeography, 30, 1161-1171.

ROSA, R. S. 1980. Lista sistemática de peixes marinhos da Paraíba (Brasil). Rev. Nordest. Biol.,
3(2): 205-226.

ROSS, S. W. \& RHODE, F. C. 2004. The gobioid fishes of North Carolina (Pisces: Gobioidei). B. Mar Sci., 74(2): 287-323.

SANTOS, R. B., NETA, R. N. F. C. \& ALMEIDA, Z. S. 2003. Características da Pesca Artesanal em três comunidades da Ilha de São Luís, Maranhão. Bol. Lab. Hidrobiol., 16: 55-65.

SARMENTO-SOARES, L. M., MAZZONI, R. \& MARTINS-PINHEIRO, R. F. 2007. A fauna de peixes na bacia do Rio Peruípe, extremo Sul da Bahia. Biota Neotrop., 7(3): 291-308.

SMITH, C. L. 1997. National Audubon Society field guide to tropical marine fishes of the Caribbean, the Gulf of Mexico, Florida, the Bahamas, and Bermuda. New York: Alfred A. Knopf. 720 p.

SOARES, L. S., SILVA JÚNIOR, M. G. da, CASTRO, A. C. L. \& SAINT PAUL, U. 2011. Comunidade de Peixes como Indicador de Qualidade Ambiental de alguns canais de Maré do Estuário do Rio Paciência, São Luís - MA. Bol. Lab. Hidrobiol., 24: $1-16$

SOUSA, M. R. J., CASTRO, A. C. L. \& SILVA, M. H. L. 2011. Comunidade de peixes como indicador de qualidade ambiental na área de influência da indústria Alumar, Ilha de São Luís - MA. Bol. Lab. Hidrobiol., 24: 1-8.

VENDEL, A. L. \& CHAVES, P. T. 2006. Use of an estuarine environment (Barra do Saí lagoon, Brazil) as nursery by fish. Rev. Bras. Zool., 23 (4): 1117-1122. 


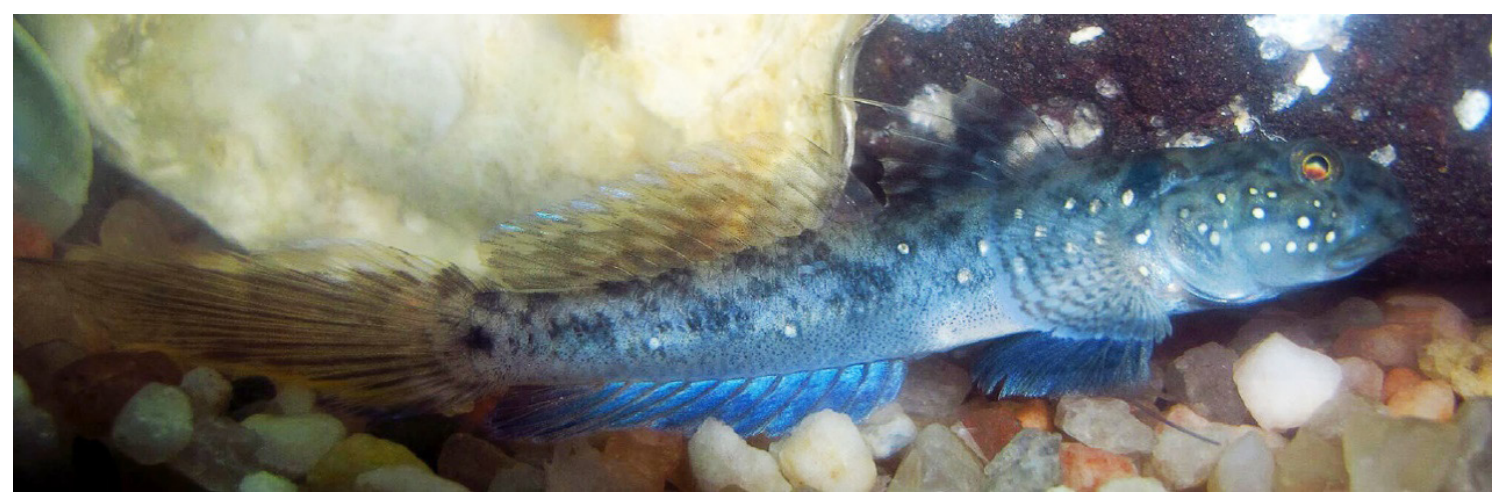

Figure 1. Ctenogobius smaragdus: CICCAA 00203, $69.8 \mathrm{~mm}$ SL specimen; Raposa Channel Estuary, Maranhão State, Brazilian Amazon Coast.

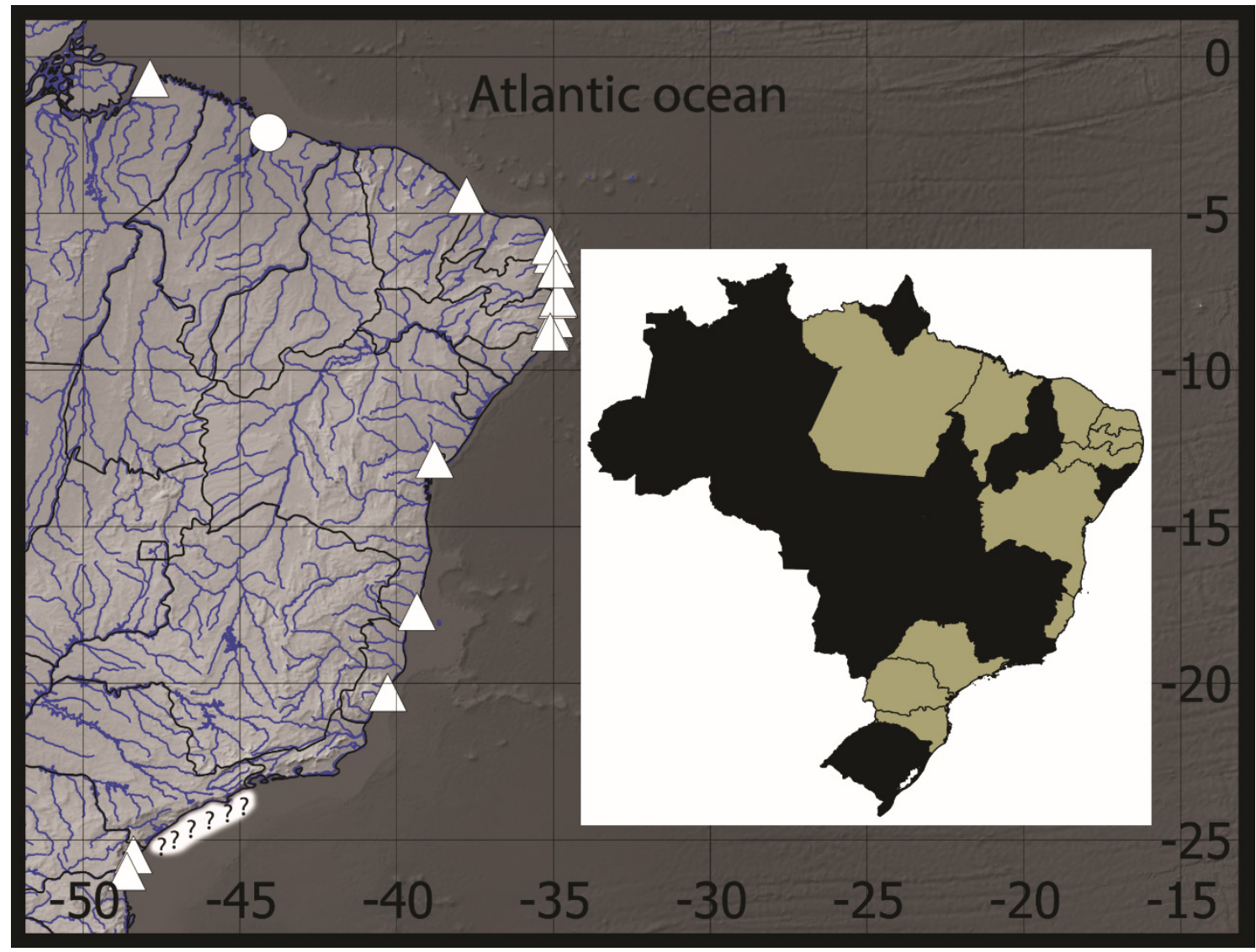

Figure 2. Records of Ctenogobius smaragdus in Brazil. Gray areas in inset represent Brazilian states where the species is recorded; white circle represents new record for the Raposa Channel Estuary, Maranhão State, Brazilian Amazon Coast, white triangle, records based on the literature (Rosa, 1980; Alves \& Filho, 1996; Joyeux et al., 2004; Mourão \& Nordi, 2006; Vendel \& Chaves, 2006; Sarmento-Soares et al., 2007; Paiva et al., 2008; Gomes-Filho \& Rosa, 2009; Paiva \& Araujo, 2010; Reis-Filho et al., 2010; Passos et al., 2012; Lima-Filho, 2015; Oliveira et al., 2016; Froese \& Pauly, 2018; Fricke et al., 2019); and records on white area with “?”based on Menezes (2011), who reported the species in the estuarine region of São Paulo state, without specific localities. 


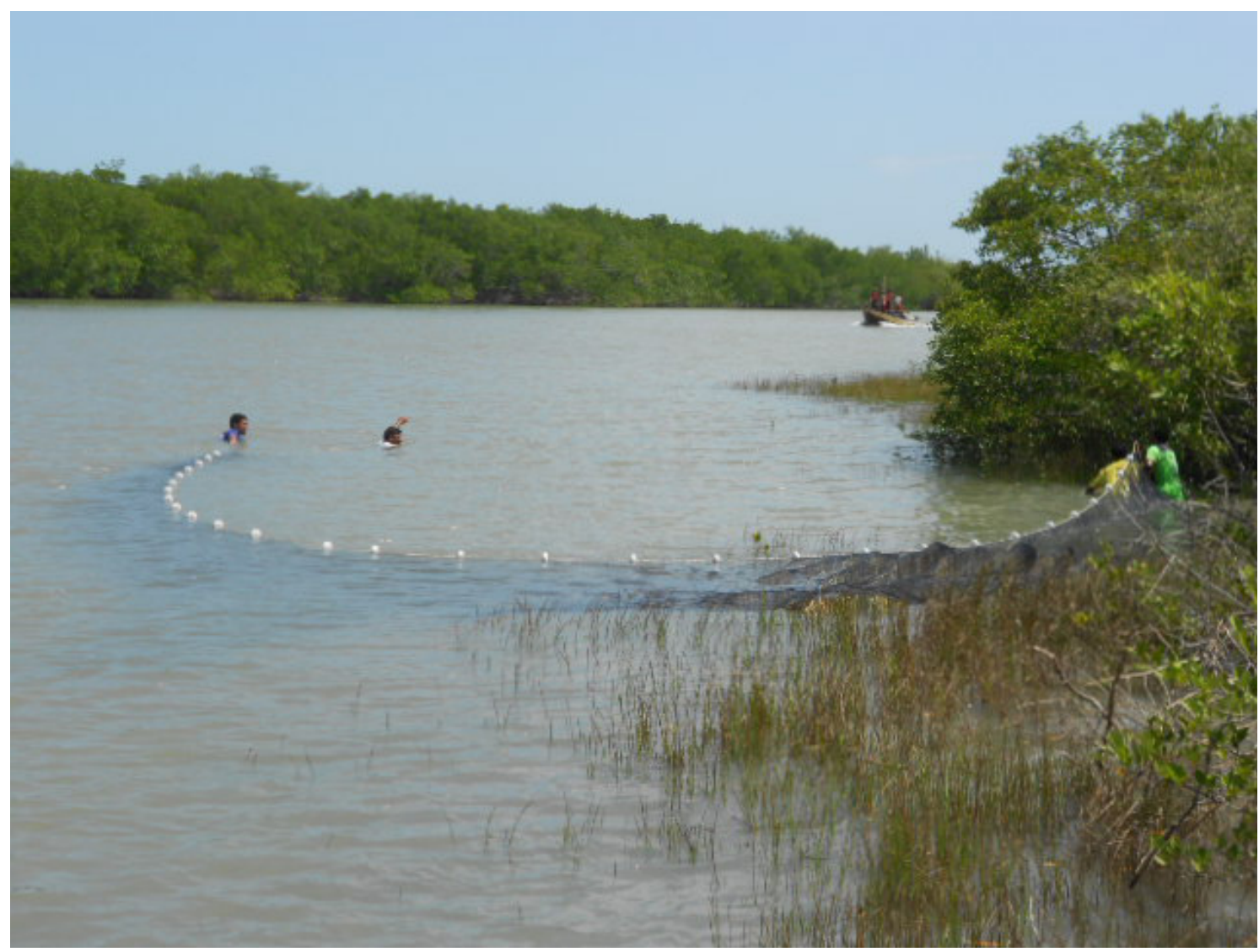

Figure 3. Collecting site of Ctenogobius smaragdus; Raposa Channel Estuary, Maranhão State, Brazilian Amazon Coast. 